Karpenko Oleksandr

D. Sc. (Public Administration),

Chairman of Information Policy

and Digital Technologies Faculty,

National Academy of Public Administration,

under the President of Ukraine

ORCID 0000-0002-9301-7973

dr.karpenko@ukr.net

\title{
THE "OVERTON WINDOW" AS MANIPULATIVE MECHANISM OF PUBLIC VALUES TRANSFORMATION
}

The purpose of the article is the implementation of the scientific and theoretical substantiation of the "Overton Window" concept as a method of applying manipulative technologies on the mass consciousness influence in order to change public values. Methodology. The research uses general scientific and special methods, in particular: inductive and deductive method, the method of analysis and synthesis, dialectic method, system, and structural-functional analysis, the method of empirical data ranking. Scientific novelty is to prove the universality of the "Overton Window" as a model of policy change in the process of interaction between its producers ("society $\leftrightarrow$ authority"), in which: the choice of alternatives to socially-oriented administrative decisions of stakeholders (officeholder) takes place under the influence of public opinion in order to provide electoral support to the target audience (direct impact of the impact of "society $\rightarrow$ authority"); The choice of alternatives to managerial decisions is made by stakeholders (office managers) independently, influencing society (creating the necessary or changing the existing attitude of target audiences), in particular through manipulation with the conscious and unconscious (the reverse effect of influence: "society $\leftarrow$ authority"). Conclusions. As a result of the research, the danger of the "Overton Window" concept used for the transformation of public values in Ukraine has been proved and practical recommendations for protecting the mass consciousness from the manipulative technologies influence have been suggested.

Key words: public values; cultural values; "Overton Window"; mass consciousness; manipulative technologies; digital society.

Карпенко Олександр Валентинович, доктор наук з державного управління, завідувач кафедри інфрормаційної політики та цифрових технологій Національної академії державного управління при Президентові України

"Вікно Овертона" як маніпуляитивний механізм трансформації суспільних цінностей

Метою роботи $є$ здійснення науково-теоретичного обґрунтування концепції "Вікно Овертона" як методики застосування маніпулятивних технологій впливу на масову свідомість з метою зміни суспільних цінностей. Методологія дослідження. У дослідженні використано загальнонаукові й спеціальні методи, зокрема: індуктивний та дедуктивний метод, метод аналізу та синтезу, діалектичний метод, метод системного та структурно-функціонального аналізу, метод ранжування емпіричних даних. Наукова новизна полягає в доведені універсальності концепції "Вікно Овертона" як моделі вибору змін політики ("model of policy change") в процесі взаємовпливу її виробників ("суспільства ↔ влада"), за якої: вибір альтернатив суспільно-орієнтованих управлінських рішень стейкхолдерів (офісхолдерів) відбувається під впливом громадської думки з метою забезпечення електоральної підтримки цільової аудиторії (пряма дія впливу "суспільство $\rightarrow$ влада"); вибір альтернатив управлінських рішень стейкхолдери (офісхолдери) здійснюють самостійно, впливаючи на суспільство (формуючи необхідне або змінюючи існуюче ставлення цільових аудиторій), зокрема через маніпулювання 3 свідомим та несвідомим (зворотня дія впливу: "суспільство $\leftarrow$ влада"). Висновки. В результаті дослідження доведено небезпечність наслідків застосування концепції "Вікно Овертона" для трансформації суспільних цінностей в Україні та запропоновано практичні рекомендації щодо захисту масової свідомості від впливу маніпулятивних технологій.

Ключові слова: суспільні цінності; культурні цінності; Вікно Овертона; масова свідомість; маніпулятивні технології; цифрове суспільство.

Карпенко Александр Валентинович, доктор наук государственного управления, заведующий кафедрой инфрормационной политики и цифровых технологий Национальной академии государственного управления при Президенте Украины

"Окно Овертона" как манипулятивный механизм трансформации общественных ценностей

Целью работы является осуществление научно-теоретического обоснования концепции "Окно Овертона" как методики применения манипулятивных технологий для воздействия на массовое сознание с целью изменения общественных ценностей. Методология исследования. В исследовании использованы общенаучные и специальные методы, в частности: индуктивный и дедуктивный метод, метод анализа и синтеза, диалектический метод, метод системного и структурнофункционального анализа, метод ранжирования эмпирических данных. Научная новизна заключается в доказательстве универсальности концепции "Окно Овертона" как модели выбора изменений политики ("model of policy change") в процессе взаимовлияния субъектов ее формирования и реализации ("общества $\leftrightarrow$ власть"), при которой: выбор альтернатив общественноориентированных управленческих решений стейкхолдеров (офисхолдерив ) происходит под влиянием общественного мнения с целью обеспечения электоральной поддержки целевой аудитории (прямое действие влияния "общество $\rightarrow$ власть"); стейкхолдеры (офисхолдеры) самостоятельно осуществляют выбор альтернатив управленческих решений, воздействуя на общество (формируя необходимое или изменяя существующее отношение целевых аудиторий), в том числе путем манипулирования с сознательным и бессознательным (обратное действие воздействия: "общество $\rightarrow$ власть"); Выводы. В результате исследования доказано опасность последствий применения концепции "Окно Овертон" для трансформации общественных ценностей в Украине и предложены практические рекомендации по защите массового сознания от влияния манипулятивных технологий.

Ключевые слова: общественные ценности; культурные ценности; Окно Овертона; массовое сознание, манипулятивные технологии; цифровое общество.

The relevance of the research topic. The aspects of instruments and tools for mass consciousness manipulating has become especially relevant in the scientific literature, media, and social networks after the release of the Glenn Beck's bestseller "Overton Window" on the American book market in 2010. [1] The discussion is about the existence of a societies' communicative management method in order to change their cultural, social and national values. The "step-based" implementation of this technology is the movement of 
"Overton Window ", which changes the range of possibilities from the stage of "unthinkable" values and morals of society to the "actual policy" stage, when values transformation has taken place, which is why openly supported by society, promoted and legally regulated. However, there are other [2] views on the existence of such technology and its application in practice.

Scientific coverage of the problem. The problematic of the "Overton Window" concept usage in Ukraine is low investigated unlike in the United States and Europe. In this context, we should mention the works of such scholars as Joseph Lehman, Roger Farmer, Jackson Rawlings, Robert E Kelly. Instead, the urgency of the question "can we" be considered "Window of Overton" by the method of implementing various manipulative technologies that, in the context of conducting hybrid wars, spread in the world geopolitical space in order to transform mass consciousness and existing systems of values (cultural, social, educational, national, etc.)?

Problem statement. The scientific and theoretical substantiation of the "Overton Window" concept as manipulative technology applying method for the mass consciousness influence in order to change the public values.

The methodology of the study. The research uses general scientific and special methods, in particular: inductive and deductive method, a method of analysis and synthesis, dialectic method, system, and structural-functional analysis, the method of empirical data ranking.

Theoretical basis and results. A well-known political scientist J. Overton, vice president (1992-2003) of the Macln's Science and Education Center for Public Policy (Makino Island, Michigan, USA) believed that only certain products and results of public policy development would be positively (politically) acceptable for society. The "Overton Window " concept was developed by him in the middle of 1990 in the form of a model of the choice of a stacker (officeholder) of the public policy of alternative variants (possibilities) of administrative decisions acceptable for society. The indicated "model of policy change" is a mechanism for justifying changes (or how changes occur) to public policy as a result of changes in public opinion. The boundaries of the "Overton Window" (or "Windows of Political Possibilities") options are determined by the expediency of the direct policymakers on behalf of the state in order to obtain maximum support from the electoral masses. According to J.Overton, at some point in time, a certain "window of opportunity" was opened, the boundaries of which are defined by the state of mass consciousness or social upheavals under the influence of certain events (revolutions, wars, catastrophes, epidemics, etc.). If "the politician is able to feel these boundaries and at the same time can't miss them, then he will be successful, if the politician doesn't see the limitations of the window of political opportunities and falls out of him, suggesting what the society is not ready for, then he will inevitably lose in the political arena". The "Overton Window" is transforming or moving when it's necessary to apply different or new ideas of change that arise not in state authorities but in the society that chooses these state authorities. So, the "Window of Political Opportunities", in its opinion, does not include those measures which would be considered to be effective by the actors themselves in the formulation of public policy, but those that they could support in order to provide support to society itself or to the political authority they are represented. In addition, the conceptual model of "Overton Window" is used in The United States by some public authorities' think tanks, political parties, non-governmental organizations to model alternative-necessary changes (their sequence and interconnection) in developing public policies for specific sectors (education, energy, social security, safety, etc.) [3].

Any set of consistent policy measures for a particular area/industry can be organized from the minimum to the maximum state intervention. Between its "non-interference" and "monopoly", is a step-by-step implementation of a detailed range of alternative measures that change state policy from one "extreme" to another. In accordance with the society's mood (after analyzing the public opinion of the selected target audience), within the "window of political opportunities" are those adjacent alternatives to the implementation of policies that at this time are acceptable to the population. It is clear that outside the window the ideas are politically unacceptable (at risk) at the present time, but later the situation may change due to a change in sentiment in society, and therefore the "window" can either move or be transformed in size, covering a larger or fewer alternatives (adjacent government-management, political decisions), changing the possible on the impossible, and vice versa.

One of the functions of $\mathrm{J}$. Overton's conceptual model is not only the substantiation for choosing alternatives but also the development of effective costs (mechanisms) for public policy making (government decision-making) that exist for a certain period of time which, being politically impossible now, will become politically inevitable in the future. (projected to fall into the window of "political opportunities window"). It is the forecasting of the focus (spectrum) of future shifts in state policy that allows government executives to exercise proper strategic governance, along with a situational selection of one or another alternative in favor of society's mood changing.

The "Overton Window" is a specific "selection menu" for those who want to influence the processes of developing (formulating and implementing) public policies. There are cases where the authorities (politicians) legislate political solutions outside of "the window of opportunity", but only if they are indisputable leaders of the country, otherwise they may be unpopular among the population, which will cause appropriate resistance of the population. Regardless of who exactly "moves the window," sharp political changes are always preceded by social changes caused by certain upheavals of society, regardless of who or what pro- 
vokes them. When the overwhelming majority of society is united around sound principles, values or a common idea, the government consolidates (pro-government political forces unite) to formulate goals and implement the corresponding public policy tasks. Consolidated ideas (principles, values) are a powerful force for the future, so those politicians who want to manage social development must form and invest in society. Instead, it is impossible to immediately introduce a certain idea of reform into the process of public policy making, for example, by immediately adopting certain legal and subordinate acts (which is often done in Ukraine in favor of certain lobby groups). Society needs some time to realize this idea, in other words, it is necessary to form an appropriate public opinion, by applying certain technologies of influence on mass consciousness/unconsciousness. Thus, any purpose of the "Overton Window" is associated with gradual changes in mass consciousness/unconsciousness.

Dividing the thoughts of his followers and interpreters D. Leman and G. Blake, we note the versatility of the model that is open and can work in the opposite direction: "Unthinkable" $\rightarrow$ "Radical" $\rightarrow$ "Acceptable" $\rightarrow$ "Sensible" $\rightarrow$ "Popular" $\rightarrow$ "Actual policy" (Fig.1.). Often, according to state policymakers, alternatives outside the "window" are more reasonable, rational and effective, but are unpopular among the population (for example: raising the retirement age, reducing social payments, increasing utility tariffs, legalizing drugs, etc.) Therefore, it is necessary to apply technologies of legitimate influence on public opinion in order to obtain the result acceptable for the politician. As noted above, according to George Overton, politicians do not define themselves as politically acceptable, reacting to their activities only on the needs of society, whereas the practice of using mass-conscious / unconscious manipulation technologies proves otherwise: public policymakers can successfully move the "window", changing the range of acceptability of the implementation of political opportunities, affecting society directly (for example, through bringing to the mass consciousness of truthful and objective information about the real reasons for the need to make unpopular decisions) or indirectly (for example, through manipulation of the subconscious / unconscious).

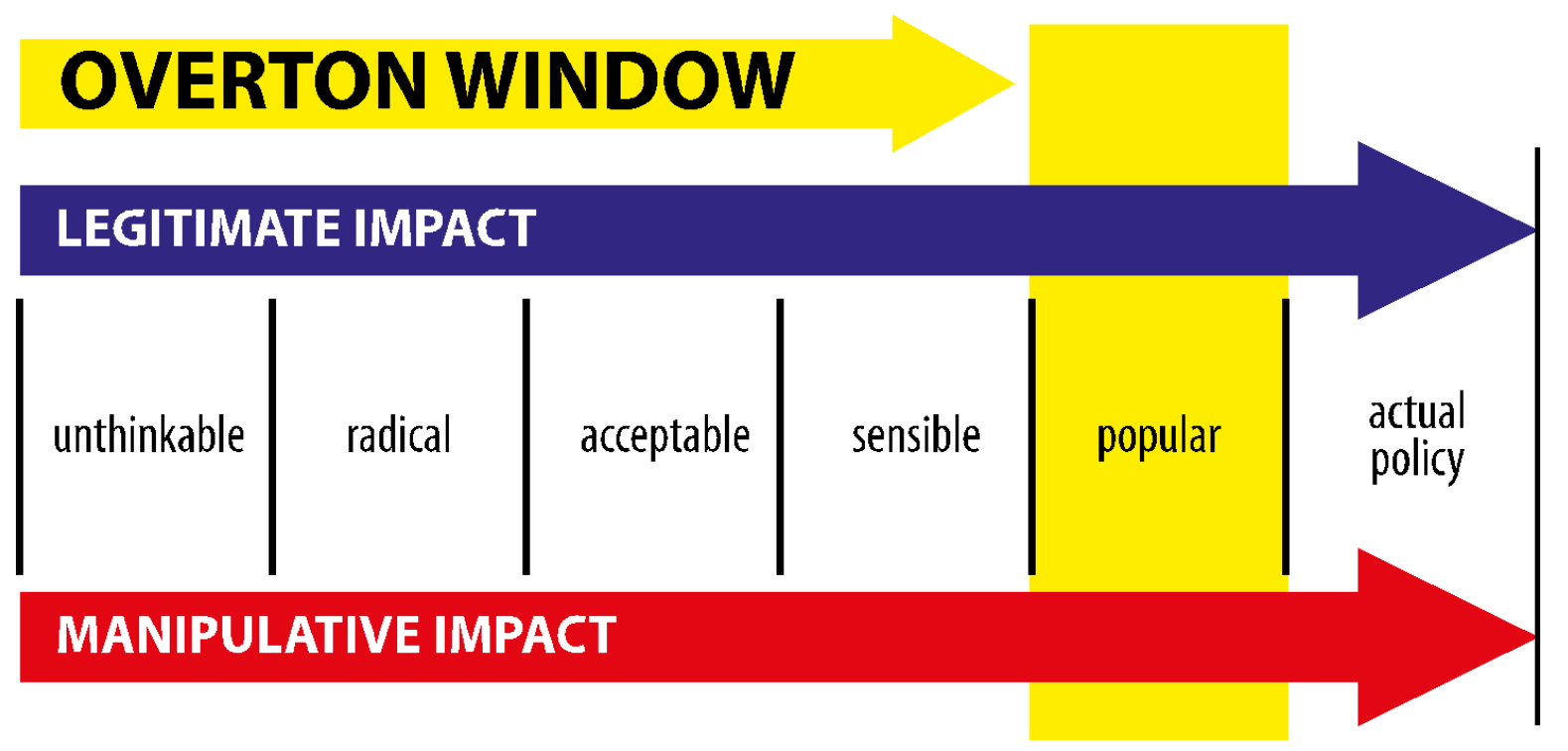

Fig.1. Overton Window: legitimate and manipulative impact

Within the frame of geopolitical confrontations in the context of the renewal of world bipolarity on the one hand and globalization processes on the other, the manipulative technologies used as a means of implementing information influence can change not only the mass consciousness, cultural values, but also the individual's social behavior. Manipulation of the collective conscious/unconscious is primarily aimed at influencing the psyche of each individual in order to create the public opinion necessary for the owner (certain issues) and provoking the conscious/unconscious actions necessary for him in the society.

An example of changes in human values is the same-sex marriages legalization, the legalization of euthanasia and abortion, the gradual implementation of the policy of "childfree" (for the reduction of the population), the constant promotion of gender choice (the gender of public relations), as well as the transformation of educational values. Concerning the latter, over the past 20 years, under the influence of external factors, Ukrainian society has become different in thinking of modern educational systems, the purpose of which has changed from the creation of the person-creator (creator) to a qualified consumer, who, instead of creating, is capable of qualitatively using the results creativity of others (to use achievements). The global trend of personalized learning has shifted towards cheap mass education through modern digital social technologies.

The scientific novelty. The basis of the "Overtone Window" concept is a universal model of policy change choices in the process of interaction between its producers ("society $\leftrightarrow$ authority"), in which: the choice of alternatives to socially-oriented administrative decisions of stakeholders (officeholder) is influenced 
public opinion in order to provide electoral support to the target audience (direct impact of the impact of "society $\rightarrow$ authority"); The choice of alternatives to managerial decisions is made by stakeholders (office managers) independently, influencing society (creating the necessary or changing the existing attitude of target audiences), in particular through manipulation with the conscious and unconscious (the reverse effect of influence: "society $\leftarrow$ authority").

Conclusion. As a result of the research of the of the "Overton Window" concept origins, as well as the analysis of the possibilities of manipulative application of its methodology for changing social, cultural, social, educational values, we have formed a number of conclusions and recommendations:

1. The "Overton Window" concept as the scientific theory of the choice of changes public policy in the process of mutual influence of its producers (office managers, stakeholders) and society (public, target audience) is substantiated.

2. It is proved that the "Overton Window" theory is based on the model of the choice of sociallyoriented management decisions ("model of policy change"), which is used to introduce new ideas for public policy development (justification for choosing changes, developing effective costs, forecasting the spectrum of future alternatives) for the implementation of proper strategic and situational governance.

3. The universality of the justification mechanism of changes in the " Overton Window" model, which consists in the possibility of its use in the opposite direction in order to apply technologies of influence (in particular, manipulative) on the mass consciousness/unconscious, is established. Public policymakers can independently change alternatives (spectrum) of their formation and implementation, influencing society directly (through bringing to the mass consciousness true and objective information about the real reasons for the need to make managerial decisions) or indirectly (through the use of manipulations from subconscious/unconscious).

4. It is proved that J.Overton's "window" moves freely in democratic societies where the values of multiculturalism are produced and unisex culture is propagated. The effective mechanism of protecting mass consciousness in Ukraine from the influence of manipulative technologies of the "Overton Window" method (or counteracting its application) is recommended to consider the implementation of state communication campaigns aimed at propagating the basic components of the system of national values, namely: cultural traditions, Ukrainian folklore and language; personalized national education; patriotic, moral and ethical and religious education on the basis of a single canonical Orthodox Church of Ukraine.

\section{תimepamypa}

1. Beck G. The Overton Window / Glenn Beck, Kevin Balfe, Emily Bestler, Jack Henderson (June 15, 2010) // Published June 15th 2010 by Threshold Editions Hardcover, $321 \mathrm{p}$.

2. Steven Levingston, Glenn Beck's paranoid thriller, "The Overton Window". The Washington Post, June 15, 2010. URL: http://www.washingtonpost.com/wp-dyn/content/article/2010/06/14/AR2010061405423.html

3. Окна Овертона". Правда и вымысел. Livejournal, 2014. URL: http://nousaction.livejournal.com/6002.html

4. Lehman J. The Overton Window. Mackinac Center for Public Policy, 2010. URL: https://www.mackinac.org/12887.

\section{References}

1. Beck G. (June 15, 2010). The Overton Window. Glenn Beck, Kevin Balfe, Emily Bestler, Jack Henderson. Published June 15th, 2010 by Threshold Editions Hardcover [in English].

2. Steven Levingston (2010). Glenn Beck's paranoid thriller, "The Overton Window." Steven Levingston. The Washington Post, June 15, 2010. Made of access: http://www.washingtonpost.com/wp-dyn/content/article/2010/06/14/AR2010061405423.html [in English].

3. "Okna Overtona." (n.d.). "The Overton Window." Truth and fiction. Available at: http://nousaction. livejournal.com/6002.htm [in English].

4. Lehman J. (2010). The Overton Window. Mackinac Center for Public Policy. Made of access: https://www.mackinac.org/12887 [in English]. 